DOI: $10.1515 /$ rpp-2015-0055

Postgraduate student, OLGA KOMOCHKOVA

Khmelnytskyi National University, Ukraine

Address: 11 Instytutska St., Khmelnytskyi, 29016, Ukraine

E-mail: olga1807komochkova@gmail.com

\title{
STRATEGIES OF HIGHER EDUCATION INSTITUTIONS DEVELOPMENT IN GREAT BRITAIN
}

\begin{abstract}
The current stage of higher education sector transformation in Ukraine has been indicated. The study of foreign experience, namely of Great Britain, and the use of positive aspects of such experience have been justified. Information sources of Universities UK (Universities UK Strategic Plan 2013-2018; Efficiency and Effectiveness in Higher Education: A report by the Universities UK Efficiency and Modernisation Task Group; Annual Report and Consolidated Financial Statements of UUK) and The Strategic Plan 2009-2015 of Lancaster University have been studied. Vision, mission, functions,pressing issues, strategic aims of the Strategic Plan of UUK for the next five years have been presented. The achievements of UKK for 2013-2014 in accordance with strategic aims have been outlined. The actions of the organization aimed at providing British universities with various supports have been presented. The constituents of Strategic Plan of Lancaster University for 2009-2015, namely vision, mission, sectors of development (International, Teaching, Research and Impact, Finance and Organisation, the Lancaster experience) and consequently successfully achieved results have been presented. Positive aspects of British experience in strategic development of higher education institutions have been defined. Perspectives for further researches in this area have been outlined.
\end{abstract}

Key words: strategic development, strategic plan, higher education institution, higher education sector, education reform, Great Britain.

\section{INTRODUCTION}

The current stage of the global and domestic economy transformation involves the creation of a knowledge-based society, where social and economic welfare of the country is determined by knowledge-based technologies, innovative orientation and level of intellectual development of society. In the context of globalization and increasing competition development of education market is of fundamental importance for the national economy.

Higher education reform, launched last summer, has marked the beginning of fundamental changes in education, namely a draft of Conception of Education Development for 2015-2025 has been developed; National Quality Assurance Agency for Education has been initiated; Ukrainian universities have been granted autonomy.

According to the Minister of Education and Science of Ukraine S. Kvit "educational potential is one of the few competitive advantages of Ukraine at the current critical stage of our history. But this is only potential. To reveal and realize it appropriate conditions should be prepared" (Українська правда, 2015).

Thus, higher education institutions of Ukraine require thoughtful direction of development that would enable better distribution of time and resources and consequently creation (selection) of a unique strategy, as well as methods and models to achieve it. Since 
the first direction of Conception of Education Development is to bring the structure of education to the needs of modern economy and Ukraine's integration into European economic and cultural space, it is necessary to study the experience of European countries, in particular, Great Britain. This choice is dictated by the fact that, in our opinion, British universities have gained the prestige in the world, and the government, various organizations and the management of higher education institutions of Great Britain, in their turn, do their best to improve the higher education system and promote professional competencies development as well.

\section{THE AIM OF THE STUDY}

The research aims at: 1) studying strategic plans of different organizations, namely UUK, and higher education institutions, in particular, Lancaster University; 2) outlining positive aspects of British experience in strategic development of universities for their further implementation into higher education system of Ukraine.

\section{THEORETICAL FRAMEWORK AND RESEARCH METHODS}

Theoretical framework of our research consists of policies, reports and corporate plans of Universities UK (UUK), namely Universities UK Strategic Plan 2013-2018 as mission, vision and strategic aims of the organisation are presented there; Efficiency and Effectiveness in Higher Education: A report by the Universities UK Efficiency and Modernisation Task Group as recommendations for ensuring value for money are indicated there; Annual Report and Consolidated Financial Statements of UUK, since there have been outlined the positive results for higher education achieved by the organization in a year (2013-2014).

Also we have referred to the strategic plans of universities, namely Lancaster University, as it is of importance to become acquainted with visions and missions the universities have defined to improve teaching, learning and research and higher education in general.

In our research we have used such methods as theoretical synthesis, theoretical analysis, generalization, and systematization.

\section{RESULTS}

Of our scientific interest has become the representative organization of universities called the Universities of the United Kingdom (UK Universities (UUK)), founded in 1918, aimed at the strategic development of British higher education institutions at both national and international levels. UKK has 133 members and represents all universities in Great Britain and Northern Ireland. It should be mentioned that all the members are vicechancellors or principals of British higher education institutions "which have met the criteria for membership agreed by the board of UUK" (Universities UK. Our Structure, Membership, 2015).

British universities are autonomous institutions that have complete freedom in determining their own priorities and mission. It is the autonomy of higher education institutions UKK sees the main advantage of the higher education sector and contributes to its preservation. At the same time collaboration with UKK allows higher education institutions to improve and achieve the ultimate goal of educational activities, such as providing diverse needs of participants in the educational process - students and teachers. For this purpose UKK has developed Strategic Plan 2013-2018, where the possibilities of these objectives achievement are outlined.

"By 2018 we want to see a thriving and diverse university sector whose teaching, scholarship and research are at the heart of the UK'S economic growth, its cultural and social life, and its global reach and influence" (Universities UK Strategic Plan, 2013). 
The main role of UKK is to support the participants, i.e. higher education institutions in achieving goals and objectives. The key functions of the organization are:

1) policy development, advocacy, analysis, and research;

2) representing the sector, influencing, media, and political engagement;

3 ) providing information and services for members;

4) providing infrastructure services for the sector as a whole in specific areas (Universities UK Strategic Plan, 2013).

In the Strategic Plan 2013-2018 a number of pressing issues have been identified which the organization plans to work on during 2013-2018:

1) the economic importance and influence of the UK's universities;

2) the value of university education:

3) supporting university engagement with a changing global environment, including increasing engagement internationally and with Europe; education;

4) university interaction with other areas of public and civic life beyond higher

5) taking a UK-wide approach, working across all four countries of the UK where relevant and appropriate (Universities UK Strategic Plan, 2013).

After consulting with members, staff and other stakeholders, UKK has developed 4 strategic aims for the next five years:

1. Inform and influence the future agenda for the UK university sector.

Projects and activities within this task are aimed at improving the sphere of public finance, economic policy, online-learning, regulation and management of data and their accessibility, studying the impact of technology on higher education, strengthening international partnerships, monitoring data reports and analytical projects.

2. Support universities in their primary aims of educating students, carrying out research and innovation, and strengthening civic society (Universities UK Strategic Plan, 2013).

Priority projects of the Strategic Plan 2013-2018 are aimed at developing research and innovation, improving social mobility, admission, health care sector, strengthening interaction of a student with the community, promoting internationalization (including strengthening relations with Europe).

3. Provide excellent services for UUK members and the UK university sector as a whole (Universities UK Strategic Plan, 2013).

Work in this area includes improving the efficiency and modernization of projects, search for opportunities of higher education sector providing with infrastructure services, analysis of the labour market, and organization of useful and timely briefings, conferences and meetings.

4. Be an effective and efficient organization (Universities UK Strategic Plan, 2013).

Activities under this task are the result of abovementioned tasks and serve as the basis for the success of the organization, as significant changes in society require professional actions for better adaption to the new requirements and confirmation of high results of its own work.

In the document "Efficiency and Effectiveness in Higher Education: A report by the Universities UK Efficiency and Modernisation Task Group" there is a paragraph 3 called "The need to do more: enhancing effectiveness and efficiency in higher education", where it is highlighted that the top priority strategic aim for all higher education institutions are undoubtedly the effectiveness and value for money.

The subparagraph 3.2 is also relevant to our study, namely the Strategy for further development, which provides guidance for the successful implementation of the tasks 


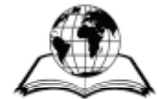

mentioned in paragraph 3. We consider it appropriate to present those recommendations within our study:

1) identifying those areas where more effective or sector wide approaches and coordination of efficiency initiatives might be necessary to overcome duplication and fragmentation;

2) identifying barriers that need to be overcome to achieve change;

3) highlighting good practice and how this can be shared more effectively;

4) developing mechanisms for more effective monitoring and increasing transparency as a driver for efficiency;

5) identifying areas where change can be brought about through strengthened leadership;

6) setting challenging goals where significant change is needed (Efficiency and Effectiveness in Higher Education: A report by the Universities UK Efficiency and Modernisation Task Group, 2011).

The Minister of Education and Science of Ukraine S. Kvit indicates that "since the beginning of 2015 Ukrainian universities and research institutions have the right to be served in the banks", meaning that "they individually determine how they will spend their own funds. However, the task of implementing full financial autonomy makes us move on" (Українська правда, 2015).

Thus, rather perspective we consider more thorough study of "Efficiency and Effectiveness in Higher Education: A report by the Universities UK Efficiency and Modernisation Task Group" in view of the transformation processes taking place in the higher education sector of Ukraine as positive aspects of the experience of UUK, in our opinion, will be useful for strategic development of the higher education funding in Ukraine.

Yearly UUK presents its own achievements in higher education in accordance with the aims outlined in the Strategic Plan in the form of a report, made by the Board of Universities UK. The report also includes information on the amendments to the projects and actions aimed at realization of the Strategic Plan.

"The Annual Report and Consolidated Financial Statements of UUK" outlines the positive changes in higher education policy for British universities, including the following:

- reductions to the higher education budget have been minimized;

- funding in UK universities has been improved;

- "The positive impact of the higher education sector on the development of local communities and the national economy" report has been published;

- a significant contribution to the development of the first Strategy of International Education has been made.

Also there have been presented actions of the organization aimed at providing British universities with various supports:

- "Efficiency and Effectiveness in Higher Education" report have been published;

- cooperation programs of universities with local economic partnerships have been developed;

- reasons of reducing the number of part-time students have been revealed and justified;

- different forums, conferences and seminars have been organized.

Thus, as we can see, Universities UK is a powerful body enabling the strategic development of higher education sector on legislative basis as well as by providing higher education institutions with different kinds of services.

As it was mentioned before we have studied Strategic Plan of Lancaster University for 2009-2015 to get acquainted with vision, mission and strategic aims of the higher education establishment. 
Lancaster University was founded quite recently, in 1964, but today it is already considered one of the best research universities, included in the list of ten best universities in the UK and hundred best universities in the world.

The vision of the university consists in ensuring own sustainable development to be recognized as leading in the world, and it can be achieved by assuring quality of learning, teaching, research and strengthening collaboration between teachers and alumni.

The mission of the university is "to pursue research at the highest international level, creating new knowledge and expertly transmitting the benefits of this to our students, partners and users of our research" (Lancaster University, 2009).

To sustain the realization of the vision and mission the task group of Lancaster universities has indentified seven fields of strategic development, namely International, Teaching, Research and Impact, Finance and Organisation, the Lancaster experience.

The number of international students has been largely increased, as alumni almost from one hundred countries all over the world constitute graduate school of the university while the academic staff consist almost one third of international staff. The mechanisms for the achievement of such great results are:

1) incorporation of international perspectives into developments, career planning, staff appraisal schemes;

2) international profile raising through recognition of international work in different faculties (Lancaster University, 2009).

According to the national surveys of students the latter assess the Lancaster University as "an elite teaching institution" (Lancaster University, 2009), since the main priorities of the university for 2009-2015 were delivering high standard programmes and employability improvement both on national and international labour markets.

Research grant income of the university has been increased by $45 \%$ over the last five years and currently the Lancaster University is working with more than 1000 enterprises. This has become possible due to 1) increasing the proportion of university staff that are recognised as world leaders in their fields; 2) ensuring that all of university's research is of international quality; 3) by supporting research from a wide range of funding sources (Lancaster University, 2009).

Lancaster University is also aimed at satisfying different needs of the alumni and staff. First of all students are supported and encouraged to develop their transferrable skills by means of intensive study and pursuing possibilities to implement these skills into practice. Second of all, study programs and qualifications are developed in such a way to have "real-world" applicability (Lancaster University, 2009.) Concerning the teaching staff, their personal and professional development is promoted and a high standard of performance from all staff is ensured. It should be mentioned that according to the National Student Satisfaction Survey of 2008 Lancaster University was ranked as top in the NorthWest and the staff claimed to be satisfied with working conditions at the university.

Since 2013 Lancaster University has been actively investing in college residential and social facilities as well as refurbishing teaching spaces and consequently has ensured the sustainable development of the campus of high standards.

Speaking about financial sustainability, successful financial management has been ensured and therefore the university has achieved high productivity in the context of difficult economic environment. It has become possible by "diversifying income sources, maintaining a balance between payroll and non-payroll costs systematically expanding existing income streams and ensuring that the full costs of our activities are identified and provided for" (Lancaster University, 2009). 
As you can see, Lancaster University can be proud of its own achievements, since it has been included in top lists of both national and international top ranking lists; students have highly assessed the professionalism of the teaching staff; the working conditions within the university have been considered perfect by the teaching staff.

\section{CONCLUSIONS}

Thus, the strategies of higher education development in Great Britain are developed by a representative organization called Universities United Kingdom (UUK). The organization represents and protects the interests of higher education institutions, including improving public policy in higher education of Great Britain; cooperates with the media and international, particularly European organizations; provides various support to higher education institutions. According to UUK the main advantage of the higher education sector is the autonomy, and therefore the organization directs its activities and projects to its preservation. Annually a monitoring report is published, where major achievements are outlined in the accordance with defined strategic aims.

Higher educational institutions, in their turn, develop their own strategic plans. For example, the Strategic Plan 2009-2015 of Lancaster University has demonstrated results achieved in 6 years, namely: leadership at the national and global levels has been strengthened, quality research has been significantly increased; the potential of the teaching staff and alumni has been unleashed.

So, the study of the experience of European countries, in particular Great Britain, in strategic development of higher education sector and universities, taking into account the positive aspects of this experience and their implementation in the national higher education sector, will be useful for native educators in elaborating strategic plans of development and selecting mechanisms to ensure education quality.

Further detailed study of policy documents of UUK and other organizations of such kind and consequently taking into account positive aspects of their experience we consider perspective in the view of crucial changes in higher education of Ukraine.

\section{REFERENCES}

1. Lancaster University. (2009). Strategic Plan 2009-2015. Retrieved 22.05.2015 from: http://www.lancaster.ac.uk/media/lancasteruniversity/contentassets/documents/research/stra tegic-plan.pdf.

2. Universities UK. (2014). Annual Report and Consolidated Financial Statements of UUK. Retrieved 20.05.2015 from : http://www.universitiesuk.ac.uk/aboutus/whatwedo/D ocuments/AnnualReportAndFinancialStatements2014.pdf.

3. Universities UK. (2011). Efficiency and Effectiveness in Higher Education: A report by the Universities UK Efficiency and Modernisation Task Group. Retrieved 21.05.2015 from: http://www.universitiesuk.ac.uk/highereducation/Documents/2011/EfficiencyinHigherEduc ation.pdf.

4. Universities UK. (2015). Our Structure. Membership. Retrieved 27.05.2015 from : http://www.universitiesuk.ac.uk/aboutus/OurOrganisation/Pages/Structure.aspx.

5. Universities UK. (2013). Universities UK Strategic Plan 2013-2018. Retrieved 20.05.2015 from : http://www.universitiesuk.ac.uk/aboutus/whatwedo/Documents/UUKStr ategicPlan2013_2018.pdf.

6. Потрібні зміни: зміст і завдання освітніх реформ [Changes Needed : Content and Objectives of Education Reforms]. (2015, January 27). Українська правда [Ukrainian Truth]. Retrieved 20.05.2015 from : http://www.pravda.com.ua/articles/2015/01/27/7056516/. 